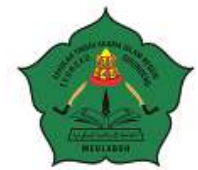

AT-TASYRI' Jurnal Ilmiah Prodi Muamalah

P-ISSN: 2085-2541, E-ISSN: 2715-7865

Volume 13, Nomor 2, Desember 2021

https://ejournal.staindirundeng.ac.id/index.php/Tasyri

\title{
DETERMINANTS OF SERVICE QUALITY ON ISLAMIC BANKS CUSTOMER SATISFACTION IN SURAKARTA
}

\author{
Fuad Hasyim \\ UIN Raden Mas Said Surakarta \\ hasyimfuad19@gmail.com
}

\begin{abstract}
Abstrak
Penelitian ini bertujuan untuk mengetahui pengaruh Banking Service Quality (BSQ)sebagai turunan dari riset SERVQUAL terhadap kepuasan nasabah Bank Syariah Indonesia Kantor Cabang Surakarta. Sampel diambil dengan teknik convenience sampling dan mendapatkan 96 responden. Instrumen pengumpulan data berupa kuesioner. Hasil penelitian menunjukkan tiga dari enam dimensi BSQ yang meliputi effectiveness and assurance, acces dan reliability berpengaruh terhadap kepuasan pelanggan. Sementara tiga lainnya, yakni price, tangibles dan services portfolio tidak berpengaruh terhadap Kepuasan Nasabah.
\end{abstract}

Kata Kunci: BSQ, Kepuasan Nasabah, Bank Syariah

\begin{abstract}
This study aims to determine the effect of Banking Service Quality (BSQ) as a derivative of SERVQUAL research on customer satisfaction at Bank Syariah Indonesia Surakarta Branch Office. The sample was taken by convenience sampling technique and got 96 respondents. The data collection instrument is a questionnaire. The results showed that three of the six dimensions of the BSQ which include effectiveness and assurance, access and reliability have an effect on customer satisfaction. While the other three, namely price, tangibles and services portfolio have no effect on customer satisfaction.
\end{abstract}

Keyword: BSQ, Consumer Satisfaction, Islamic Bank

\section{A. INTRODUCTION}

The development of Islamic banks in Indonesia today is growing rapidly. Indonesia is one of the largest Muslim countries in the world so it has a big role in building a sharia economy. Especially with the birth of a giant Islamic bank in the country, namely Bank Syariah Indonesia (BSI). The result of the merger or merger of three state-owned banks, including Bank Mandiri Syariah, Bank BNI Syariah, and Bank BRI Syariah. The presence of Bank Syariah Indonesia (BSI) is a new milestone for this nation. With the unification of Islamic banks, Indonesia is targeted to become the center of Islamic economy and finance in the world.

\begin{tabular}{|c|c|c|c|c|c|}
\hline & & $\begin{array}{l}\text { Asset } \\
\text { Total }\end{array}$ & Financing & $\begin{array}{l}\text { Third- } \\
\text { party } \\
\text { funds }\end{array}$ & Profit \\
\hline \multirow[t]{2}{*}{ BNIS } & 2019 & 44,98 & 43,77 & 32,58 & 0,6 \\
\hline & 2020 & 55,01 & 47,97 & 33,05 & 0,5 \\
\hline \multirow[t]{2}{*}{ BSM } & 2019 & 43,12 & 34,12 & 27,38 & 0,074 \\
\hline & 2020 & 57,7 & 49,34 & 40 & 0,25 \\
\hline \multirow[t]{2}{*}{ BRIS } & 2019 & 112,29 & 99,81 & 75,54 & 1,28 \\
\hline & 2020 & 126,85 & 112,58 & 83,43 & 1,43 \\
\hline BSI & 2020 & 239,56 & 209,98 & 156,51 & 2,19 \\
\hline
\end{tabular}

Source: Data Processed 
Therefore, Islamic banks are faced with the target of increasing market share, which so far has only been around 5\%. Therefore, Islamic banks are required to build customer satisfaction. In building customer satisfaction, service quality is one of the key success factors of a bank as a service company and cannot be denied in today's business world, because nothing is more important for a banking company to place the problem of customer satisfaction through service as one of its business commitments. . If the service provided by the customer is good and satisfactory, it will have a positive effect on business performance, otherwise the service provided to the customer is unsatisfactory, it will have a negative effect on business performance.

The company's competitive advantage can be done by providing products or services at a more affordable cost, fast processing, and providing the best service to customers. In the world of banking, service quality plays an important role in managing the company to meet customer needs in order to achieve a level of satisfaction (Lovelock, 1988). Every customer does not only use the product or service, but also considers all aspects of the service that the product has.

The best service acts as a standard measure of success in providing guarantees for customer satisfaction. To increase trust and customer loyalty, they must be able to provide an objective assessment of service quality (Melinda, 2017). Efforts in creating customer satisfaction are not easy. If the bank's production is difficult to imitate, so the difference from other banks is in the services provided.

The best service will give the impression of increasing customer satisfaction and loyalty (Miranti, 2008). Both practitioners and experts argue that customer satisfaction and loyalty are related to each other (Oliver, 1980). As revealed (Jones, 1994) there is a positive correlation between customer loyalty and customer satisfaction.

An important finding in the development of service quality measurement (SERVQUAL) in the relationship marketing literature is the concept of customer satisfaction or dissatisfaction with a service. Many previous studies provide an important note that today's market, especially for customers, has begun to experience significant changes in the demands of service quality that are in line with their expectations. Management in accordance with customer needs and expectations is the right strategic direction for banking companies. Then the quality of service becomes a guideline for banks in completing and meeting every customer's needs and expectations, even though it is not an easy job (Parasuraman, 1990).

Some researchers think that having service quality is the main achievement. Therefore, this study positions service quality and in order to achieve customer satisfaction (Jayachandran et al., 2005). For a bank that wants to win the competition, it must be able to achieve a certain level of quality, both product quality and quality from other aspects such as HR efficiency, which is able to make product prices competitive and able to provide good service. According to Parasuraman, (1990) quality service can be achieved if the service is in accordance with or better than customer expectations. And in accordance with the times, the expectations of these customers are increasing.

To determine the quality of a service (SERVQUAL) in banking used a method called Banking Service Quality (BSQ) developed by Bahia and Nantel, which consists of: access (access), price (price) and tangible (tangible) (Bahia dan Nantel 2000). This measurement is the development of the 
marketing mix framework or what is commonly called the 7P by Booms and Bitner. In research by Wijaya et al., (2017) it shows that the variables that have a positive effect on customer satisfaction of Islamic banks are the variable price (price), service portfolio (portfolio of services offered), reliability (reliability), and tangible (realization).

Various literatures consider quality service as the main strategy in achieving the success and sustainability of the company's life. Companies must be able to satisfy their customers, especially those in the service department (Khaliq 2018). The task of Islamic banks is to be able to imitate service quality programs that aim to increase the provision of products and services to their customers and solve the problem of intense competition between newcomers to the market and conventional banks (Othman, 2001).

An example of a way to increase the chances of business success in the service sector is how to provide superior quality services (Rohmati, 2017). The quality of service is improved because it aims at customer satisfaction. Profits/profits can be obtained easily if the customer's satisfaction level has been met (Marimin, 2018). Efforts to answer challenges in bank competition must always maintain the quality of its services so that it can be used as a guide to where the quality of services provided, as well as the level of customer satisfaction with the acquisition of services that have been provided (Yuli, 2012).

\section{B. LITERTURE REVIEW Service Quality (SERVQUAL)}

Service Quality is how far the difference between the expectations and reality of customers for the service they receive. Service Quality can be identified by comparing customer perceptions of the service they actually receive with the actual service they expect. Service quality is the main thing that is seriously considered by the company, which involves all the resources owned by the company.

These service quality dimensions can be used to measure the service quality of a service company. Measuring service quality means evaluating or comparing the performance of a service with a set of predetermined standards (Tjiptono, 2008; Tjiptono \& Fandy, 2015). For the measurement model, Parasuraman et al., (1985) has created a multi-item scale called SERVQUAL. The SERVQUAL scale was first published in 1988, and consists of twenty-two question items, which are thoroughly distributed on the five dimensions of service quality.

The SERVQUAL scale is intended to measure customer expectations and perceptions, and the gaps that exist in the service quality model. Measurements can be made using a Likert Scale or Differential Semantics, and respondents only need to choose the degree of their agreement or disagreement with questions regarding the delivery of service quality. If the perceived service is as expected, the service quality is perceived as good and satisfactory. If the service received exceeds consumer expectations, then the service quality is perceived as an ideal quality. On the other hand, if the service received is lower, than expected, the service quality is perceived as poor. Thus whether or not the quality of service depends on the ability of service providers to consistently meet consumer expectations.

Parasuraman et al., (1985) stated that services have the following characteristics:

1. Intangible, means that services are not like physical products. Services cannot 
be tasted, seen, smelled, or heard before they are purchased. Given its nonexistence, service providers often find it difficult to know customer perceptions and evaluate their quality.

2. Inseparable, meaning that services are generally produced and consumed simultaneously. The consumer is present at the time the service is performed so that there is an interaction between the service provider and the consumer who is the special characteristics of service recipients. Both service providers and consumers will affect the results and services.

3. Heterogeneity, means that services vary greatly depending on who provides, when and where the service is performed. Consistency Personal service behavior is difficult to guarantee so that what has been provided by the service provider may be entirely different from what the customer receives.

4. Perishability, services are products that cannot be stored as inventory. If the services offered are not used, it will be a loss that must be borne by the company. The implication for banking is that nondurable service products will not be a problem if the demand is constant, because the company can arrange its staff in advance to provide services. However, if demand fluctuates, then demand forecasting and good planning are very important to be able to produce services that meet consumer needs.

\section{Banking Service Quality (BSQ)}

Banking Service Quality is a derivative of the service quality theory (SERVQUAL) from Parasuraman which is combined with the TP Kotler concept developed by Bahia and Nantel. Bahia \& Nantel (2000) explain that efforts to realize service quality standards from a banking service company can use the BSQ dimension. Several aspects become standards of measurement in the quality of banking services, namely:

1. Effectiveness and assurance

Reliability of employees in generating trust in consumers. This dimension can be formed by 13 units consisting of: Level of trust, Equal recognition of all customers, Confidentiality of all customer data and transactions, Service to customers, Time management in service, Professionalism and reliability possessed by employees, Employee knowledge related to customers, Not experiencing problems between employees and management, Providing services according to the initial commitment, Maintaining good quality, Feeling safe, Not delaying caused by policies and bureaucracy. Quality communication.

2. Access

The company's ability to make it easier for information to be contacted or found (approachability). Several items from the access dimension, among others: The number of acceptable ATM services, Tools that are always up to date, sufficient Teller and Customer Service, Easy Call center to be contacted, Effective transaction process.

3. Price

The suitability of services issued by banking companies to funds that have been issued by customers. The price dimension is formed from several items, namely: Distributing information that is easy for customers to understand, Clear details relating to service fees, Amount of equivalent costs in services, Administration fees that are comparable to services provided,

4. Tangibles 
Fuad Hasyim, Determinants of Service Quality on Islamic Banks Customer...

The company's ability to show presence to external parties. Appearance and physical facilities, as well as conditions in the surrounding environment, as evidence include 4 items: Infrastructure, adequate equipment and tools, Appearance of employees, Safe and clean environment.

5. Portfolio Service

Fulfillment of services by the banking sector as an effort to provide convenience for transactions for customers. Dimensions formed on the service portfolio (service portfolio), namely: Complete and adequate services, Stable service achievement with banking in general.

6. Reliability

The company is able to provide services that are properly described. The company was able to provide services from the first time. In addition, the company must be consistent in realizing the agreement according to what has been determined. Several items from the reliability dimension are as follows: reliability in order to gain trust (dependability), work consistency (performance), the same service without distinguishing each customer, punctuality.

Bahia \& Nantel (2000) suggest that the renewal method as a standard for measuring service quality in the banking industry is commonly referred to as Bank Service Quality (BSQ). BSQ was developed because of the evidence that the method is more effective and better than SERVQUAL. It can be seen in the comparison image according to the indicators of each dimension as follows.

Table 2. Banking Service Quality (BSQ)

\section{Indicator}

No Dimension Indicator

\begin{tabular}{|c|c|c|}
\hline 1 & $\begin{array}{l}\text { Effectiveness } \\
\text { and } \\
\text { Guarantee }\end{array}$ & $\begin{array}{l}\text { a. Speed in service } \\
\text { b. No delays due to } \\
\text { bureaucracy } \\
\text { c. and procedures } \\
\text { d. Security during } \\
\text { transactions }\end{array}$ \\
\hline 2 & Access & $\begin{array}{l}\text { a. Modern equipment } \\
\text { used } \\
\text { b. The number of tellers } \\
\text { and customer service } \\
\text { a. adequate } \\
\text { b. Fast queue }\end{array}$ \\
\hline 3 & Price & $\begin{array}{l}\text { a. Low administration fee } \\
\text { b. Loan interest rate } \\
\text { c. Deposit interest rate }\end{array}$ \\
\hline 4 & Tangibles & $\begin{array}{ll}\text { a. } & \text { Clear transaction } \\
\text { service instructions } \\
\text { b. Availability of } \\
\text { supporting equipment } \\
\text { c. Physical appearance } \\
\text { and tidiness of } \\
\text { employees }\end{array}$ \\
\hline 5 & $\begin{array}{l}\text { Portfolio } \\
\text { Service }\end{array}$ & $\begin{array}{l}\text { a. Phone banking and } \\
\text { SMS banking services } \\
\text { b. Interbank transfer } \\
\text { service via ATM } \\
\text { c. Payment service via } \\
\text { ATM }\end{array}$ \\
\hline 6 & Reliability & $\begin{array}{l}\text { a. The ability of } \\
\text { employees to provide } \\
\text { explanation. } \\
\text { b. There are no errors in } \\
\text { giving service. } \\
\text { c. Ability of employees } \\
\text { to make corrections } \\
\text { quickly when it } \\
\text { happens error. }\end{array}$ \\
\hline
\end{tabular}

Source: (Bahia \& Nantel, 2000)

\section{Consumer Satisfaction}

Satisfaction according to Philip Kotler (2000) is the level of perception in comparing the perceived product performance with the desired value. Satisfaction is defined as an overall assessment of the cumulative level of banking services received by customers. Satisfaction depends on the achievement of satisfactory and unsatisfactory services with the bank from time to time (Ladhari, et al. 2011). 
The level of satisfaction depends on the performance (perceived performance) with expectations (expectations). Customers will not feel enough if the company's performance is below what they want. On the other hand, customers will feel fulfilled if the performance is the same as desired. Expectations are formed from an experience in transactions, communication, and information on agreements made by the company and its competitors. If the company promises the customer's expectations are too high but the company is not able to fulfill it, it will cause disappointment to the customer. Even if customers are satisfied, companies will not get many customers if they set expectations too low.

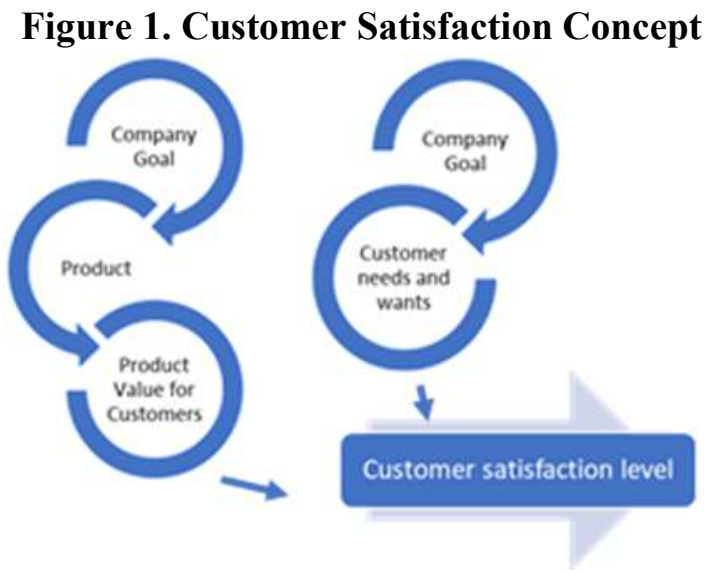

Source: Tjiptono (2008)

Efficiency is very influential on most Islamic banking today in building customer satisfaction. Haron (1994) argues that the indicators of customer satisfaction in Islamic banking are efficiency, speed, and friendliness. Khattak (2010) found that the convenience aspect of the company's infrastructure will affect customer satisfaction. Expanding the local network and branch offices as well as easy transactions are part of the convenience factor (Rashid, et al. 2009).

Confidence is the most important factor in satisfaction with the meaning of trust in the information provided by banks, trust in bank management, then trust in bank capital and asset size Increasing customer satisfaction by offering superior products, uniformity of service in each branch office, as well as the best marketing program in service availability is referred to as the term Core Banking. Khattak (2010) suggests that a significant influence on customer satisfaction comes from the cost-benefit factor. As a consideration received by the customer in the cost-benefit can be in the form of lower costs and returns (Rashid, et al. 2009).

Another technique to measure customer satisfaction is to use attributes that contain how customers value a product or service from the customer's point of view. According to Dutka (1994) there are attributes that can form satisfaction consisting of:

1. Attributes related to the product

2. Attributes related to the service

3. Attributes related to the purchase

\section{Hypothesis Development}

Effectiveness \& Assurance, this refers to effective service delivery (especially friendliness and courtesy of employees) and the ability to provide a feeling of security. Assurance is defined as the skills to communicate as well as to handle the privacy of customer requests. Trust in the banking system is closely related to effectiveness (Spathis, Petridou, and Glaveli 2004).

H1: Effectiveness and assurance affect customer satisfaction.

Access, assessing the speed of service delivery. Easy access is the most important thing for banks and their customers, because most customers want to be able to transact with banks in a broad way without restrictions wherever they go. This is a demand and emphasis in getting quality service. This is done by, for example, ATM (Automatic Teller Machine) (Narteh 2013), Mobile 
Banking (Akturan and Tezcan 2012) and Internet Banking (Laforet and Li 2005).

$\mathrm{H}_{2}$ : Access affects customer satisfaction.

Price, measures the costs associated with service administration. Banks generally have options for determining fees and funds that must be paid by customers according to the number of transaction values, personal relationships with banks and bargaining power by customers. Kim, Kim, and Lennon (2006) show that price fairness affects customer trust and satisfaction with service providers.

$H_{3}$ : Price has an effect on customer satisfaction.

Tangibles, assessing the appearance and cleanliness of the physical infrastructure owned by the bank. Mersha, Tigineh Sriram (2012) argues that tangibles create a practical product or service so that it is easy to use by customers. Mukherjee and Nath (2003) found that investing in tangible features alone could not solve the problem of consumer dissatisfaction in banks. Jr. (2001) concluded that the tangibles dimension as an agent in evaluating service outcomes, but tangibles cannot be determined as a descriptor.

$\mathrm{H}_{4}$ : Tangibles has an effect on customer satisfaction.

Service Portfolio, assessing the reach, consistency, and product innovation of the bank. In the banking industry, customers expect a complete set of services that must be communicated and provided to them appropriately. The perception of the bank's service quality that continues to promote the latest and innovative products allows high ratings by most consumers. Technological developments have helped drive new processes, products and services in the banking sector. As with clearing transactions, checks have drastically reduced, while opportunities for mobile banking have increased. The provision of ATMs, Internet Banking and SMS alerts also brings information advancement techniques to customers (Dimyati et al., 2020).

$H_{5}$ : Service portfolio has an effect on customer satisfaction.

Reliability, the ability of banks to provide services in accordance with the agreement and be able to minimize existing errors. Reliability is an indicator that is often used as a standard for measuring service quality and the strongest predictor is found in obtaining customer satisfaction (Wolfinbarger dan Gilly 2003).

H6: Reliability affects customer satisfaction.

\section{METHODOLOGY}

This research uses quantitative research, so it requires data in numerical form (Sarwono, 2012). The definition of quantitative research is a research activity that is based on the philosophy of positivism and becomes a form of a population or a particular research sample. The research tool is used as data collection, while the data analysis is statistical, and aims as a reference to predetermined assumptions. In this quantitative approach, it is used to measure the level of customer satisfaction using the Banking Service Quality (BSQ) dimension.

The components of a population are referred to as samples. If the population is large, it is impossible for the whole population to be studied by researchers, such as limitations in energy, time, and cost, so that researchers only take part of the population. The conclusion from the sample that will be implemented on the mandatory population is representative (Sugiyono, 2015). The sampling technique used was convenience random sampling. Due to the unknown population of Bank Syariah Indonesia customers at the Surakarta Branch Office, 
Lemeshow's formula is more appropriate to obtain a large number of samples (Riduwan dan Akdon, 2009):

$$
\begin{aligned}
& n=\frac{\mathrm{Z} \alpha^{2} \times \mathrm{P} \times \mathrm{Q}}{L^{2}} \\
& n=\frac{(1,96)^{2} \times 0,5 \times 0,5}{(0,1)^{2}} \\
& n=96,04
\end{aligned}
$$

Based on the above calculation, a minimum sample of 96.04 is obtained so that it can be rounded up to a minimum of 96 respondents from customers who open accounts at Bank Syariah Indonesia Surakarta branch offices for more than one year.

This study uses primary data. Primary data, namely data sources produced without intermediaries from the original source or from the first party. Primary data collection is used as a result of answering research questions or research activities (Sugiyono, 2017). Data collection was obtained using a self-administered report questionnaire (question list). Respondents were asked to fill out the questionnaire individually. Then in this research activity, questionnaires were distributed directly to respondents, in addition to making it easier to do in other ways such as asking respondents to fill out the questionnaire through the google form that has been given. The basic form that is used as a reference in this questionnaire is closedended questions, the meaning is the form of questions or statements by making various responses so that they know the characteristics of the respondents. Scaled response questions are questions and statements using Likert scale measurements, aimed at measuring and knowing the level of customer satisfaction and expectations related to the products and services being researched, viewed from the customer side (Anggraeni \& Yasa, 2012).
The data obtained from the questionnaire results were then processed using the SPSS program with the Multiple linear regression method, which is a method that examines the effect of the independent variable on one dependent variable (Ghozali, 2013). To provide certainty that the regression equation obtained has accuracy in estimation, is unbiased and consistent, it is first tested with the classical assumption test which includes:

a. normality test, which is to see if the data is normally distributed

b. heteroscedasticity test, which is to find out whether the distribution of data is homogeneous or heterogeneous

c. multicollinearity test, to determine whether the regression model found a correlation between independent variables heteroscedasticity test, to predict the model built (Suharyadi \& Purwanto, 2016)

\section{Demography}

Before conducting the analysis of data processing in this study, it is necessary to present a description of the various characteristics of the respondents in an effort to complete and strengthen the research. Some of the characteristics described include gender, age, last education, occupation, income, year of account opening, and savings products used in opening accounts by respondents. In this study, the respondents were customers who opened a savings account at Bank Syariah Indonesia at the Surakarta Branch Office for at least one year when the research was conducted. The general description can be described as follows:

Table 3: Respondent Demography

\begin{tabular}{lclc}
\hline \multicolumn{1}{c}{ Item } & \% & \multicolumn{1}{c}{ Item } & \% \\
\hline \multicolumn{1}{c}{ Gender } & \multicolumn{1}{c}{ Age } \\
\hline Male & $28 \%$ & $<18$ Year & $2 \%$ \\
Female & $72 \%$ & $18-25$ Year & $77 \%$ \\
\hline
\end{tabular}


Fuad Hasyim, Determinants of Service Quality on Islamic Banks Customer...

\begin{tabular}{|c|c|c|c|}
\hline & $25-50$ Year & $19 \%$ \\
\hline & & $>50$ Year & $2 \%$ \\
\hline \multicolumn{2}{|c|}{ Education } & \multicolumn{2}{|l|}{ Occupation } \\
\hline Elementary & $10 \%$ & Student & $53 \%$ \\
\hline Junior High & $23 \%$ & PNS/TNI/POLRI & $5 \%$ \\
\hline Senior High & $37 \%$ & Private & $9 \%$ \\
\hline \multirow{2}{*}{ Undergraduate } & $30 \%$ & Housewife & $3 \%$ \\
\hline & & Other & $30 \%$ \\
\hline \multicolumn{2}{|c|}{ Income (Rp. Million) } & \multicolumn{2}{|c|}{ Account Opening } \\
\hline$<1$ & $53 \%$ & 2014 & $1 \%$ \\
\hline $1-3$ & $27 \%$ & 2015 & $1 \%$ \\
\hline $3-5$ & $5 \%$ & 2016 & $2 \%$ \\
\hline \multirow[t]{4}{*}{$>5$} & $5 \%$ & 2017 & $3 \%$ \\
\hline & & 2018 & $20 \%$ \\
\hline & & 2019 & $47 \%$ \\
\hline & & 2020 & $26 \%$ \\
\hline
\end{tabular}

Source: Data Processed

\begin{tabular}{llllll} 
X4.3 & .634 & X5.3 & .204 & X6.3 & .562 \\
X4.4 & .447 & X5.4 & .434 & X6.4 & .606 \\
& & X5.5 & .475 & X6.5 & .674 \\
\hline
\end{tabular}

Source: Data Processed

Based on the table, it can be seen that the calculated $r$ value for each question item is greater than the $r$ table of 0.200 . It can be concluded that each question item passed the validity test.

\section{Reliability}

Reliability has the meaning of being trusted so that it can be relied upon (Arikunto, 2010). A reliable test is useful for measuring the consistency of measuring instruments that are used many times at different times but the results are the same. Reliability is the constancy of measurement. In terms of measuring instruments, the concept of reliability is related to the problem of error where the error shows the extent to which the inconsistency of the measurement results occurs if repeated measurements are carried out on the same subject group (Ghozali, 2013). So it can be stated that reliability is related to freedom from bias, stability and consistency (Suryani \& Hendryadi, 2015). The alpha of a variable looks reliable or reliable when the alpha value is $>0.6$.

Table 4. Reliability Test

questionnaire so that it can actually measure what it wants to measure. Valid questionnaires are those that contain questions that are able to reveal something that will be measured by the questionnaire itself. The questionnaire is said to be valid if there is a real correlation between the two variables based on a significant level of 0.05 where $r$ count $>r$ table (Ghozali, 2013). The results of the validity test in this study are as follows:

Table 4: Validity Test

\begin{tabular}{llllll}
\hline Item & r count & Item & r count & Item & r count \\
\hline $\mathrm{X} 1.1$ & .527 & $\mathrm{X} 2.1$ & .438 & $\mathrm{X} 3.1$ & .634 \\
$\mathrm{X} 1.2$ & .666 & $\mathrm{X} 2.2$ & .546 & $\mathrm{X} 3.2$ & .595 \\
$\mathrm{X} 1.3$ & .663 & $\mathrm{X} 2.3$ & .573 & $\mathrm{X} 3.4$ & .647 \\
$\mathrm{X} 1.4$ & .434 & $\mathrm{X} 2.4$ & .556 & $\mathrm{X} 3.5$ & .593 \\
$\mathrm{X} 1.5$ & .684 & $\mathrm{X} 2.5$ & .622 & $\mathrm{X} 3.6$ & .659 \\
\hline $\mathrm{X} 4.1$ & .559 & $\mathrm{X} 5.1$ & .451 & $\mathrm{X} 6.1$ & .480 \\
$\mathrm{X} 4.2$ & .586 & $\mathrm{X} 5.2$ & .573 & $\mathrm{X} 6.2$ & .275 \\
\hline
\end{tabular}

\begin{tabular}{lc}
\hline \multicolumn{1}{c}{ Variable } & Cronbach's Alpha \\
\hline Effectiveness and Assurance & .804 \\
Access & .772 \\
Price & .828 \\
Tangibles & .757 \\
Service Portfolio & .664 \\
Reliability & .742 \\
Consumer Satisfaction & .864
\end{tabular}

Source: Data Processed

Based on the table of reliability test results on Cronbach's Alpha each variable is greater than 0.6. So it can be seen that the measuring instrument used is reliable and trustworthy.

\section{Classical Asumption Normality}

Normality test to see in the regression model whether the data has a normal 
distribution or not. In this test there is a test method by graphical analysis and by means of the Kolmogorov Smirnov test. Based on the tests carried out the results in this study are as follows:

Table 5. Normality Test

One-Sample Kolmogorov-Smirnov Test

\begin{tabular}{llr}
\hline & & $\begin{array}{c}\text { Unstandardized } \\
\text { Residual }\end{array}$ \\
\hline $\mathrm{N}$ & Mean & 96 \\
Normal Parameters $^{\mathrm{a}}$ & Std. Deviation & .0000000 \\
& & 1.09146381 \\
Most Extreme Differences & Absolute & .131 \\
& Positive & .131 \\
& Negative & -.062 \\
Kolmogorov-Smirnov Z & & 1.282 \\
Asymp. Sig. (2-tailed) & & .075 \\
\hline
\end{tabular}

a. Test distribution is Normal.

Based on the Kolmogorov test table, it produces a significance value of 0.075 . This value is greater than 0.05 so it can be said that the data in this regression model has met the assumption of normality.

\section{Multicolinierity}

Multicollinearity test to test in the regression model whether or not there is a correlation between independent variables, a good regression model does not have a correlation between the independent variables. This test can be detected by paying attention to the tolerance value and Variant Inflation Factor (VIF). The values to indicate the occurrence of multicollinearity are tolerance 0.10 and VIF 10 (Ghozali, 2011).

\section{Table 6. Multicolinearity Test}

\begin{tabular}{llrr}
\hline \multirow{2}{*}{ Model } & \multicolumn{2}{c}{ Collinearity Statistics } \\
& & & \\
\hline 1 & (Colerance & VIF \\
& X1 & .239 & 4.189 \\
X2 & .232 & 4.304 \\
& X3 & .603 & 1.657 \\
& X4 & .885 & 1.130 \\
& X5 & .360 & 2.778 \\
& X6 & .321 & 3.114 \\
\hline
\end{tabular}

a. Dependent Variable: $\mathrm{Y}$
The table above shows that the results of the multicollinearity test show that there is a tolerance value that is more than 0.1 and all VIF values are less than 10 , which means that there is no multicollinearity between independent variables.

\section{Heteroscedasticity}

Heteroscedasticity test is a test that aims to see the variance inequality from one observation residual to another observation where a good regression model is one that does not occur heteroscedasticity. This test can be done with the glejser test. If the significance value is more than 0.05 , it is considered to meet the heteroscedasticity assumption.

Table 6. Heteroscedastisity Test

\begin{tabular}{lrr}
\hline \multicolumn{1}{c}{ Model } & \multicolumn{2}{c}{ Sig. } \\
\hline (Constant) & .560 & .577 \\
X1 & -.439 & .662 \\
X2 & -.140 & .889 \\
X3 & -2.414 & .018 \\
X4 & .651 & .517 \\
X5 & 1.922 & .058 \\
X6 & .054 & .957 \\
\hline a. Dependent Variable: Abres & &
\end{tabular}

\section{Multiple Regression}

This test aims to determine the direction of the relationship between the independent variable and the dependent variable, whether each independent variable is positively or negatively related in addition to predicting the magnitude of the value of the dependent variable which is influenced by the independent variable.

Table 7. Regression Summary

\begin{tabular}{|c|r|r|r|}
\hline Model & R & R Square & $\begin{array}{c}\text { Adjusted R } \\
\text { Square }\end{array}$ \\
\hline 1 & $.901^{\mathrm{a}}$ & .812 & .799 \\
\hline
\end{tabular}
a. Predictors: (Constant), X6, X3, X4, X2, X5, X1
b. Dependent Variable: Y

\begin{tabular}{|c|c|c|c|}
\multicolumn{4}{c|}{ ANOVA $^{\mathbf{b}}$} \\
\multicolumn{1}{|c|}{ Model } & $\begin{array}{c}\text { Mean } \\
\text { Square }\end{array}$ & $\mathrm{F}$ & Sig. \\
\hline 1 Regression & 81.471 & 64.070 & $.000^{\mathrm{a}}$ \\
\end{tabular}




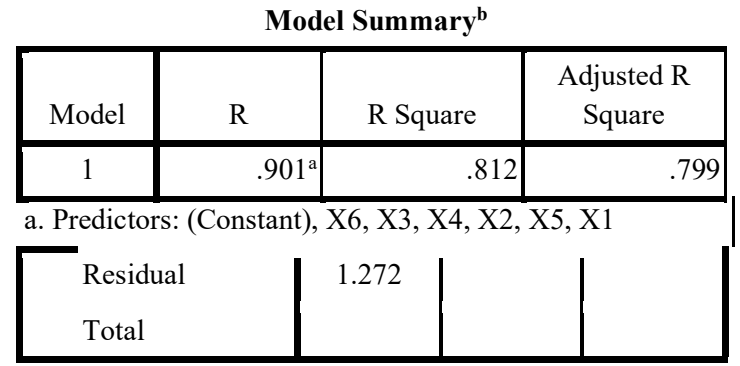

a. Predictors: (Constant), X6, X3, X4, X2, X5, X1

b. Dependent Variable: Y

\begin{tabular}{|c|c|c|c|}
\hline \multicolumn{4}{|c|}{ Coefficients $^{\mathrm{a}}$} \\
\hline \multirow[b]{2}{*}{ Model } & \multicolumn{2}{|c|}{$\begin{array}{l}\text { Unstandardized } \\
\text { Coefficients }\end{array}$} & \multirow[b]{2}{*}{ Sig. } \\
\hline & B & Std. Error & \\
\hline $1 \quad$ (Constant) & -.804 & 1.430 & .575 \\
\hline $\mathrm{X} 1$ & .579 & .097 & .000 \\
\hline $\mathrm{X} 2$ & .276 & .111 & .014 \\
\hline $\mathrm{X} 3$ & -.071 & .061 & .250 \\
\hline $\mathrm{X} 4$ & .071 & .212 & .737 \\
\hline $\mathrm{X} 5$ & .063 & .096 & .515 \\
\hline $\mathrm{X} 6$ & .185 & .091 & .044 \\
\hline
\end{tabular}

a. Dependent Variable: Y

The coefficient of determination (Adjusted R Square) test is used to obtain information on the extent to which the contribution of the independent variable (free) to the dependent variable (bound). Based on table 7 above, it is known that the value of Adjusted $\mathrm{R}^{2}$ is 0.799 , that all banking service quality (BSQ) variables are able to contribute to consumer satisfaction by $79.9 \%$. The remaining $30.01 \%$ is explained by other variables.

The F test is a tool to see whether all the independent variables in the model have a simultaneous or joint effect on the dependent variable. The basis for the decision for this test is if $\mathrm{F}$ count $>\mathrm{F}$ table and significant value $<$ alpha $(0.05)$ then $\mathrm{H}_{0}$ is rejected and $\mathrm{H}_{\mathrm{a}}$ is accepted, which means that the independent variables have a simultaneous effect on the dependent variable. Based on the table 7 , it can be seen that the calculated $F$ value is 2.068 and the $\mathrm{F}$ table is 64.070 so that the calculated $\mathrm{F}>\mathrm{F}$ table. In addition, the significance value of 0.000 is smaller than 0.05 . So it can be interpreted that the independent variables simultaneously affect customer satisfaction.

\section{Effectiveness and Assurance}

Based on the table 7, it is known that Effectiveness and Assurance has a positive and significant impact on customer satisfaction with a positive regression coefficient $(0.00<0.05)$, so the first research hypothesis is proven. If the Effectiveness and Assurance of Islamic banking services at Bank Syariah Indonesia Surakarta Branch Office, the impact on increasing customer satisfaction. This means that Effectiveness and Assurance as measured by speed of service, no delays in bureaucracy and procedures and ensuring security during transactions have an impact on customer satisfaction. Aspects that can have a significant impact on customer satisfaction of Islamic banks at Bank Syariah Indonesia Surakarta Branch Office are employees who provide the same service to every customer without distinction, bureaucracy and procedures that comply with operational standards set by Bank Syariah Indonesia Surakarta Branch Office so that there are no delays caused by bureaucracy and procedures, guaranteed security during transactions is felt by customers which causes customers to feel satisfied with the services they get from Bank Syariah Indonesia Surakarta Branch Office.

The results of this study support research from (Narteh, 2016; Lassar, et al., 2000) which found Effectiveness and Assurance had a positive effect on customer satisfaction. The effect of Effectiveness and Assurance dimensions on customer satisfaction. The most important thing in these conditions can be explained by effective services and being able to provide guarantees 
to customers. In general, customers want to get a fast service and guaranteed confidentiality. For banking, this dimension is very important because banks as service providers must focus on customer trust by providing guarantees for the funds deposited by their customers as well as possible.

\section{Access}

The results also show that Access has a significant positive impact on customer satisfaction $(0.014<0,05)$, so the second hypothesis is also proven. It can be said that if banking access increases, it will lead to an increase in customer satisfaction. Access in this study includes measuring the equipment owned by the bank in a modern way and also ensuring the convenience of customers in transacting with banks. Facts in the field as a plus point that Bank Syariah Indonesia Surakarta Branch Office has used up to date equipment in running its business, the availability of adequate tellers and customer service, which makes queues faster, so that customers are satisfied with the services of Bank Syariah Indonesia Surakarta Branch Office.

Further findings are also in line with (Narteh, 2016; Lassar, et al., 2000) that Access has a significant positive impact on customer satisfaction. The logic that can be concluded is that customers have a tendency to choose a bank that is located close to the customer's house, is easy to reach and has guaranteed security for customers. In accordance with the opinion of Allred dan Addams (2000), the most important factor is to assess the convenience and comfort factor, because customers do not want to travel long distances and spend a long time to fulfill their business, especially banking. Therefore, providing easy access to services will have an impact on increasing customer satisfaction.

\section{Price}

The results of the study prove that Price has a negative and insignificant effect on customer satisfaction $(0,250>0.05)$, so the third hypothesis is not proven. This finding does not support research from (Bedman Narteh 2016; Lassar et al. 2000), which concludes that Price has a positive impact on customer satisfaction. It is stated that there is a discrepancy between the costs borne by the customer compared to the services provided by the bank, so that the customer is still not satisfied with the fees charged to the customer.

\section{Tangibles}

The results of Tangibles' research are not proven to have a positive and significant effect on customer satisfaction $(0.737>0.05)$. These aspects include: clear instructions for transaction services provided by employees to customers, availability of adequate supporting equipment, neat physical appearance of employees and realization in the formation of a service is an important dimension, especially in banking. Banking companies must pay attention to the customer trust factor by giving a bona fide impression through tangible things, namely regarding cleanliness and facilities owned, the bank environment provides a pleasant atmosphere and the accuracy of providing account reports. Customer assessment of the dimension of realization is still considered low. This is contrary to (Spathis et al., 2004) that the better Tangibles will lead to increased customer satisfaction. Tangibles have consistently emerged as a dimension of retail service quality, retail banks that significantly influence customer service behavior.

\section{Service Portfolio}

The results of the study reject the fifth hypothesis in the study, namely Service Portfolio that has no effect on customer satisfaction. Judging from the beta coefficient 
value of $p$-values of $0.515>0.05$, in the sense that the Service Portfolio indicator of Indonesian Islamic Banks according to their customers is still not able to create customer satisfaction. This result means that the services provided by Bank Syariah Indonesia at the Surakarta Branch Office to customers are still incomplete and not fully consistent with developments in meeting customer needs and desires. This result is supported by data from open questionnaire answers by research respondents who assess that the service portfolio of Bank Syariah Indonesia at the Surakarta Branch Office is still low. Although it has provided information in the form of pamphlets or so on about mobile banking services and other services, socialization to customers is still lacking. The results of this study contradict research (Lassar et al., 2000), namely the service portfolio has a significant positive effect on customer satisfaction. These results support the research by Narteh (2016) which finds that Service Portfolio has no significant effect on the satisfaction of retail bank customers in Ghana.

\section{Reliability}

The sixth hypothesis is proven. Thus, reliability has effect on customer satisfaction $(0,044<0.05)$. The meaning of this finding is that the employees of Bank Syariah Indonesia Surakarta Branch Office according to customers have met expectations. This is supported by the fact from the answers of research respondents who assessed that although there were still employee errors in serving, the speed of employees in making corrections to the occurrence of errors and the ability of employees to provide explanations was not optimal, but in general the service was maximal. The results of this study support research by Lassar et al., (2000) which concludes that reliability has a significant positive effect on customer satisfaction.

\section{CONCLUSION}

Effectiveness and Assurance of Bank Syariah Indonesia Surakarta Branch Office has a positive and significant impact on customer satisfaction. The increasing Effectiveness and Assurance offered by Bank Syariah Indonesia Surakarta Branch Office such as speed, having a short bureaucracy and good standard operating procedures will affect customer satisfaction.

Access has a positive and significant impact on customer satisfaction. Access involves the availability of teller services with sharia bank branch networks by providing opportunities for customers to obtain banking services. In addition, this result implies that the Bank has modern equipment so that it makes it easier for customers to transact banking products.

Price has no positive and insignificant effect on customer satisfaction. This means that the cost burden to customers is still not in accordance with the services provided. In other words, the mismatch of prices charged with customer expectations is one of the barrier factors for efforts to increase customer satisfaction.

Tangibles aspect of the facility has no effect on customer satisfaction. This proves that the facilities provided to customers are still considered unable to increase customer satisfaction. The Service Portfolio is assessed by its customers as not being able to provide satisfaction to customers because it is considered incomplete and not yet fully consistent with the development of customer needs in the banking world and is considered by respondents to be still low. Reliability of Bank Syariah Indonesia Surakarta Branch Office has a positive and significant impact on customer satisfaction. So reliability is 
Fuad Hasyim, Determinants of Service Quality on Islamic Banks Customer...

considered to have been able to affect customer satisfaction or has not been able to meet expectations.

\section{BIBLIOGRAPHY}

Allred, A. T., \& Addams, H. L. (2000). Service Quality at Banks and Credit Unions: What Do Their Customers Say? Research and Concepts Service Quality at Banks and Credit Unions: What Do Their Customers Say? Managing Service Quality: An International Journal, 10(1), 52-60.

Anggraeni, \& Yasa. (2012). E-Service Quality Terhadap Kepuasan Dan Loyalitas Pelanggan Dalam Penggunaan Internet Banking. Jurnal Keuangan Dan Perbankan, 32916(2), 293-306.

Arikunto, S. (2010). Prosedur Penelitian Suatu Pendekatan Praktik Edisi Revisi cet 14. Rineka Cipta.

Bahia, K., \& Nantel, J. (2000). A reliable and valid measurement scale for the perceived service quality of banks. International Journal of Bank Marketing, 18(2), 84-91. https://doi.org/10.1108/026523200103 22994

Bedman Narteh. (2016). Service Quality and Customer Satisfaction in Ghanaian Retail Banks: The Moderating Role of Price. International Journal of Bank Marketing, 8(5), 68-88. https://doi.org/10.1108/EUM00000000 01084

Christoper H. Lovelock. (1988). Lovelock. 1988. Managing Service: Marketing, Operation, and Human Resources. London: Prentice-Hall International, Inc .

Dimyati, M., Afandi, M. F., \& Destari, F. (2020). ( Studi Bank Syariah di Kabupaten Jember ). 14(1).

Dutka. (1994). Atribut - Atribut Dari Konsumen Secara Universal. Erlangga,
Glora Aksara Pertama.

Ermina Miranti. (2008). Prospek Industri Batu Bara di Indonesia, Economic Review No. 214. https://doi.org/10.47599/bsdg.v5i1.255

Ghozali, I. (2013). Aplikasi Analisis Multivariate Dengan Program IBM SPSS 21 (7th ed.). Badan Penerbit Universitas Diponegoro.

Haron, S., Ahmad, N., \& Planisek, S. L. (1994). Bank patronage factors of muslim and non-muslim customers. International Journal of Bank Marketing, 12(1), 32-40. https://doi.org/10.1108/026523294100 49599

Jayachandran, S., Sharma, S., Kaufman, P., \& Raman, P. (2005). The role of relational information processes and technology use in customer relationship management. Journal of Marketing, 69(4), 177-192. https://doi.org/10.1509/jmkg.2005.69.4 .177

Jones, T. and W. E. S. J. (1994). Marketing (Second Edi).

Jr., M. K. B. \& J. J. C. (2001). Some New Thoughts on Conceptualizing Perceived Service Quality: A Hierarchical Approach. Journal of Marketing, 49(3), 34-39. https://doi.org/10.1007/s10840-0170265-3

Khattak, N. A. (2010). Customer satisfaction and awareness of Islamic banking system in Pakistan. African Journal of Business Management, 4(5), 662-671.

Kim, M., Kim, J. H., \& Lennon, S. J. (2006). Online service attributes available on apparel retail web sites: An E-S-QUAL approach. Managing Service Quality, 16(1), 51-77. https://doi.org/10.1108/096045206106 39964

Ladhari, R., Ladhari, I., \& Morales, M. (2011). Bank service quality: 
Fuad Hasyim, Determinants of Service Quality on Islamic Banks Customer...

Comparing Canadian and Tunisian customer perceptions. International Journal of Bank Marketing, 29(3), 224246.

https://doi.org/10.1108/026523211111 17502

Lassar, W. M., Manolis, C., \& Winsor, R. D. (2000). Service quality perspectives and satisfaction in private banking. International Journal of Bank Marketing, 18(4), 181-199. https://doi.org/10.1108/026523200103 49067

Marimin, A., \& M. (2018). Signifikansi Kualitas Jasa Terhadap Kepuasan Nasabah di Bank Syariah. RELEVANCE : Journal of Management and Business, 1(2), 92-106.

Melinda. (2017). Pengaruh E-Service Quality Terhadap E-Loyalty Pelanggan Go-Jek Melalui E-Satisfaction Pada Kategori Go-Ride. Agora, 5(1), 1.

Mersha, Tigineh Sriram, V. H. Y. Y. G. (2012). Perceived Service Quality in Ethiopian Retail Banks. Thunderbird International Business Review, 54(4), 551-565. https://doi.org/http://doi.org/ $10.1002 /$ tie

Mukherjee, A., \& Nath, P. (2003). A model of trust in online relationship banking. International Journal of Bank Marketing, 21(1), 5-15. https://doi.org/10.1108/026523203104 57767

Oliver, R. L. (1980). Congnitiv Model of the Antecedents and Consequences of Satisfaction Decision. Journal of Marketing Research, 17(9), 460-469.

Othman, A. . \& O. L. (2001). The Multi Dimensionality of Carter Model to Measure Customer Service Quality (SQ) in Islamic Banking Industry: A Study in Kuwait Finance House. International Journal of Islamic Financial Services, 3(4), 1-12.

Parasuraman, A. (1990). An empirical examination of relationships in an extended service quality model. Cambridge, Mass. : Marketing Science Institute, 1990.

Parasuraman, A., Zeithaml, V. A., \& Berry, L. L. (1985). A Conceptual Model of Service Quality and Its Implications for Future Research. Journal of Marketing, 49(4). https://doi.org/10.2307/1251430

Rashid, M., Hassan, M. K., \& Ahmad, A. U. F. (2009). Quality Perception of the Customers towards Domestic Islamic Banks in Bangladesh. Journal of Islamic Economics, Banking and Finance, 5(1), 109-131.

Restu Khaliq. (2018). Importance Performance Analysis dalam kasus Kepuasan Konsumen Usaha Laundry. 17(34), 47-64.

Riduwan dan Akdon. (2009). Aplikasi Statistika dan Metode Penelitian untuk Administrasi dan Manajemen. Dewa Ruci.

Rohmati, D., F. (2017). Implemtasi kualitas pelayanan pendekatan CARTER Karyawan, pengaruhnya terhadap kepuasan UJKS koperasi. Jurnal Ekonomi Syariah Teori Dan Terapan, 3(3), 203. https://doi.org/http://dx.doi.org/10.204 73/vol3iss20163pp203-218

Sarwono, J. (2012). Metode Riset Skripsi Pendekatan Kuantitatif (Menggunakan Prosedur SPSS): Tuntunan Praktis dalam Menyusun Skripsi.

Spathis, C., Petridou, E., \& Glaveli, N. (2004). Managing service quality in banks: Customers' gender effects. Managing Service Quality: An International Journal, 14(1), 90-102. https://doi.org/10.1108/096045204105 13695

Sugiyono. (2015). Metode Penelitian Pendidikan. Alfabeta.

Sugiyono. (2017). Metode Penelitian Bisnis (3rd ed.). Alfabeta.

Suharyadi, \& Purwanto, S. K. (2016). 
Fuad Hasyim, Determinants of Service Quality on Islamic Banks Customer...

Statistika untuk Ekonomi dan Keuangan Modern. In Statistika untuk Ekonomi dan Keuangan Modern Buku 2.

Suryani, \& Hendryadi. (2015). Metode Riset Kuantitatif: Teori Dan Aplikasi Pada Penelitian Bidang Manajemen Dan Ekonomi Islam (Pertama). Kencana.

Tjiptono. (2008). Stratergi Pemasaran. In Edisi Kedua, Penerbit Andi, Yogyakarta.

Tjiptono, \& Fandy. (2015). Strategi Pemasaran. In Yogyakarta: Andi.

Wijaya, H., Beik, I. S., \& Sartono, B. (2017). Pengaruh Kualitas Layanan Perbankan
Terhadap Kepuasan dan Loyalitas Nasabah Bank Syariah XYZ di Jakarta. Jurnal Aplikasi Bisnis Dan Manajemen, 3(3), 417-417. https://doi.org/10.17358/jabm.3.3.417

Wolfinbarger, M., \& Gilly, M. C. (2003). eTailQ: Dimensionalizing, measuring and predicting etail quality. Journal of Retailing, 79(3), 183-198. https://doi.org/10.1016/S00224359(03)00034-4

Yuli, S. B. C. (2012). Kualitas Layanan Bagi Nasabah di PT. Bank Syariah Mandiri Cabang Malang. Jurnal Humanity, 7(2), 83-97. 